\title{
STEREOTIP GENDER DAN DOMINASI KAPITALIS DALAM IKLAN TELEVISI \\ Suatu Analisis Wacana Kritis terhadap Iklan Televisi Citra Korporasi Gudang Garam di Bulan Ramadhan
}

\author{
Bhernadetta Pravita Wahyuningtyas; Endang Setiowati \\ Marketing Communication, Faculty of Economic and Communication, BINUS University \\ Jln. K. H. Syahdan No. 9, Palmerah, Jakarta Barat 11480 \\ bhernadetta@gmail.com; setiowati@gmail.com
}

\begin{abstract}
Advertising has many purposes including the formation of consciousness, creating the image of the product or brand, forming positive associations and encouraging consumer behavior. Basically, the purpose of advertising is to achieve economic hegemony of the producers of goods or service advertised. Ads are increasingly being used for the benefit of the capitalists. Corporate advertising researchers usually discuss the effects of advertising on the form of company image only. But this research is not going to reveal about the image of a company that advertised, but about the creator ideology behind the creation of a corporate Advertising. The corporate Ads examined in this study is a series of Gudang Garam corporate advertisement which consists of two ads that aired on television every Ramadan. The research method used is French critical discourse analysis and analytical method of Sara Mill. This study uses substantive theoretical framework such as hegemony, ideology, patriarchy, and Marxist feminism and the discourse analysis theory from Michael Foucault and semiotic theory of Roland Barthes. The results of this study showed that the ideology of the ad creator which is very patriarchal makes the text of the Gudang Garam corporate ads aired on all television stations every Ramadan, was laden with the existence of gender stereotypes.
\end{abstract}

Keywords: marxist feminism, patriarchal ideology, gender stereotype, capitalist domination

\begin{abstract}
ABSTRAK
Iklan memiliki berbagai tujuan, termasuk pembentukan kesadaran, menciptakan citra produk atau merek, membentuk asosiasi positif, dan mendorong perilaku konsumen. Pada dasarnya, tujuan iklan adalah untuk mencapai hegemoni ekonomi dari produsen barang atau jasa yang diiklankan. Iklan semakin sering digunakan untuk kepentingan kaum kapitalis. Perusahaan riset biasanya membicarakan dampak iklan pada bentuk citra perusahaan saja. Akan tetapi, penelitian ini tidak akan mengungkapkan tentang citra perusahaan yang diiklankan, tetapi tentang ideologi pencipta di balik penciptaan sebuah perusahaan Advertising. Iklan perusahaan yang diteliti dalam penelitian ini adalah serangkaian iklan Gudang Garam yang terdiri dari dua iklan yang ditayangkan di televisi setiap bulan Ramadan. Metode penelitian yang digunakan adalah analisis wacana kritis French dan metode analisis dari Sara Mill. Penelitian ini menggunakan kerangka teori substantif seperti hegemoni, ideologi patriarki,, dan feminisme Marxis dan analisis teori wacana dari Michael Foucault dan teori semiotik Roland Barthes. Hasil dari penelitian ini menunjukkan bahwa ideologi pencipta iklan yang sangat patriarkal membuat teks iklan Gudang Garam yang ditayangkan di semua stasiun televisi setiap bulan Ramadan, sarat dengan adanya stereotip gender.
\end{abstract}

Kata kunci: feminism marxis, ideologi patriarkal, stereotip gender, dominasi kapitalis 


\section{PENDAHULUAN}

Bulan Ramadan merupakan saat para produsen barang dan jasa menghabiskan banyak biaya untuk berpromosi di media massa. Hal ini memberikan suatu fakta akan banyaknya aneka jenis iklan yang dipasang di media massa untuk menciptakan kesadaran akan barang dan jasa yang dipromosikan. Memang periklanan adalah bagian dari kehidupan modern. Tanpa iklan para produsen dan atau distributor tidak akan dapat menjual barang dan jasanya, sedangkan di sisi lain para pembeli tidak akan memiliki informasi yang memadai mengenai produk-produk barang dan jasa yang tersedia di pasar. Kehidupan masyarakat tidak terhindar dari, dan dipengaruhi oleh terpaan iklan, baik dari iklan media elektronik maupun iklan media cetak. Periklanan memainkan peranan penting dalam dunia pemasaran, komunikasi, ekonomi dan kehidupan bermasyarakat. McQuail (2005: 85) mengatakan bahwa iklan memiliki berbagai tujuan termasuk pembentukan kesadaran, menciptakan citra produk atau merek, membentuk asosiasi positif dan mendorong perilaku konsumen. Pada dasarnya tujuan iklan memang untuk mencapai hegemoni ekonomi dari produsen barang atau jasa yang diiklankan. Iklan semakin sering digunakan untuk kepentingan kaum kapitalis.

Barran dan Davis (2000: 321-322) mengatakan ada beberapa penelitian kajian budaya kritis juga telah mengarahkan kritik mereka yang paling tajam terhadap iklan. Mereka mengatakan bahwa iklan adalah komoditas budaya yang paling hebat. Iklan membungkus pesan-pesan promosi sedemikian rupa sehingga orang akan tertarik dan bahkan bertindak mengikuti apa yang ditampilkan dalam iklan, meskipun sebenarnya orang itu tidak terlalu perhatian bahkan tidak membutuhkan barang atau jasa yang ada dalam iklan tersebut. Konsumsi terhadap barang tertentu secara rutin akan melukiskan sebuah cara terbaik untuk membentuk identitas pribadi yang seringkali tidak dipahami. Jika dibandingkan dengan isi media massa lainnya, iklan sangat berkaitan dengan pendapat Marxist tentang ideologi.

Iklan memang dimaksudkan untuk memperkuat konsumsi yang dapat melayani kepentingan pabrik-pabrik produsen barang-barang dan bukan melayani kepentingan konsumen secara pribadi. Iklan secara jelas dirancang untuk merangsek masuk dan mengganggu rutinitas kebiasaan dan keputusan dalam membeli suatu barang. Iklan mencoba untuk merangsang dan mendorong konsumsi meski jika hal itu bisa merugikan kesehatan individual untuk jangka panjang. Misalnya pada produk rokok dan alkohol, keberhasilan kampanye iklan memengaruhi orang untuk terikat dalam tindakan yang merusak diri sendiri. Dalam banyak kasus, iklan dapat dengan mudah mendorong untuk mengonsumsi barang-barang yang sebenarnya tidak terlalu berguna bagi diri sendiri, atau ternyata hanya memberi keuntungan pada produk yang diiklankan. Satu contoh yang paling nyata adalah ketika memilih untuk membeli baju dengan merek tertentu karena iklan telah mempromosikan barang tersebut sebagai suatu simbol status tertentu. Padahal baik baju yang bemerek maupun baju tak bemerek sama-sama mempunyai fungsi dasar yaitu sebagai pelindung tubuh kita (Baran and Davis, 2000: 131).

Terdapat dua jenis iklan yang biasa dibuat oleh perusahaan iklan bagi promosi kliennya, yaitu iklan produk dan iklan korporasi (Corporate Advertising). Boove dan Arens (1986: 223) menyebut ada empat jenis corporate advertising sebagai berikut. Pertama, Public Relations Advertising (PRA); iklan ini digunakan jika perusahaan ingin berkomunikasi langsung dengan salah satu publik terpentingnya dalam rangka mengekspresikan perasaannya atau menyampaikan titik pandangnya terhadap khalayak tersebut. Kedua, Corporate/Institutional Advertising; iklan ini digunakan untuk banyak tujuan seperti laporan perkembangan perusahaan; memosisikan perusahaan secara kompetitif dalam pasar; menghindarkan masalah dengan publik tertentu; merefleksikan adanya perubahan dalam kepribadian perusahaan; meningkatkan moral karyawan, dan banyak tujuan lainnya. Ketiga, Corporate Identity Advertising; umumnya digunakan untuk mengomunikasikan identitas perusahaan yang baru, seperti perubahan nama, logo atau merek dagang. Keempat, Recruitment Advertising; 
digunakan untuk memotivasi karyawan atau untuk menarik calon-calon karyawan agar bergabung dengan perusahaan.

Corporate advertising seperti disebutkan di atas digolongkan menjadi dua bagian, yaitu dua jenis yang pertama lebih bersifat umum, sementara dua jenis yang terakhir lebih memiliki tujuan yang spesisfik. Namun bila diperhatikan lebih saksama, jenis ke dua, yaitu Corporate/Institutional Advertising, lebih kerap digunakan dibandingkan Public Relations Advertising. Persoalan yang muncul kemudian ialah apakah penggunaan Corporate/Institutional Advertising bisa menghasilkan efek yang bermanfaat bagi tujuan komersial perusahaan. Bovee dan Arens menyatakan, "....that institutional advertising may be pretty or nice, but that it does not make the cash register ring". Maksudnya adalah iklan korporasi yang biasanya berbentuk indah bahkan dengan biaya yang cukup mahal, namun tidak serta merta dapat menghasilkan uang sebagaimana iklan produk. Tetapi memang biasanya iklan Corporate/Institunional Advertising banyak digunakan untuk memosisikan perusahaan secara kompetitif dalam pasar melalui penciptaan citra perusahaan (Bovee \& Arens, 1986: 199).

Salah satu perusahaan yang berpromosi melalui iklan korporasi di bulan Ramadan adalah Gudang Garam. Pada bulan Ramadan tahun 2007 ini, Gudang Garam meluncurkan dua jenis iklan korporasi yaitu versi Ibu dan Anak serta versi Potret. Versi Ibu dan Anak memfokuskan untuk menyampaikan pesan tentang kesabaran dengan tagline "hanya dengan sabar kita dapat mengendalikan diri”. Dalam iklan berdurasi 30 detik ini, digambarkan situasi komunikasi antara seorang anak laki-laki yang berusia sekitar 6 atau 7 tahun dengan ibunya yang sedang membuat kue di dapur. Dalam iklan tersebut memang yang melakukan dialog hanya si anak sementara si ibu hanya tersenyum memerhatikan celoteh si anak tentang puasa, sambil sibuk membuat kue. Sampai tiba-tiba si anak menumpahkan tepung terigu, dan si ibu terlihat berekspresi marah, tetapi langsung ditimpali dengan celoteh anak yang mengatakan bahwa kalau sedang puasa kita harus sabar dan menahan amarah. Versi Ibu dan Anak sebenarnya telah diluncurkan pada bulan Ramadan tahun 2006 yang lalu, namun pada sepuluh hari pertama bulan Ramadan tahun 2007, versi ini kembali disiarkan di semua stasiun televisi di Indonesia.

Pada hari ke sebelas hingga satu hari sebelum Lebaran, Gudang Garam meluncurkan versi Potret. Fokus pesan yang disampaikan adalah tentang refleksi diri dengan tagline "saatnya introspeksi di bulan puasa". Dalam iklan yang juga berdurasi 30 detik ini, digambarkan situasi seorang anak perempuan usia SD yang baru pulang dari sekolah, lalu tanpa berganti baju, bahkan masih membawa tas menemui ayahnya yang sedang bekerja di rumah. Ayahnya digambarkan sebagai seorang arsitek yang sedang membuat sebuah maket gedung bertingkat. Suasana rumah sangat terlihat sehingga penonton dapat menyimpulkan bahwa si ayah memang bekerja di rumah dan bukan di kantor. Setting yang berlaku dalam iklan ini sama dengan iklan versi sebelumnya, dialog hanya dilakukan oleh tokoh anak yang terus berceloteh mencurahkan perasaannya tentang kelakuan teman-temanya di sekolah yang suka bergunjing padahal hari itu adalah bulan puasa. Sementara tokoh ayah hanya tersenyum mendengarkan celoteh si anak sambil meneruskan pekerjaannya. Ending dari iklan ini adalah ketika tokoh anak menyatakan keheranannya pada ayah mengapa pada bulan puasa ada orang yang suka bergunjing, dan dibalas oleh ayahnya dengan kata "ada" sambil tokoh ayah memotret diri sang anak menggunakan kamera di telepon selulernya, lalu memperlihatkan hasil foto tersebut kepada sang anak sehingga sang anak tersenyum sipu.

Kedua iklan korporasi tersebut mempunyai kesamaan struktur penceritaan, yaitu bagaimana hubungan antara anak dan orangtua. Namun jika kita perhatikan akan tampak penempatan posisi lakilaki dan perempuan yang sangat stereotipikal. Keduanya mendiskreditkan posisi perempuan, baik sebagai seorang ibu, maupun seorang anak. Hal ini dikarenakan dalam kedua iklan itu, perempuan digambarkan sebagai sosok yang emosional dan tidak sabaran seperti yang diperankan oleh Ibu pada versi iklan Ibu dan anak (kesabaran). Sedangkan sosok anak perempuan dalam versi iklan potret (refleksi diri) digambarkan senang bergunjing, sebuah labelisasi yang ditempelkan pada perempuan. 


\section{Identifikasi Permasalahan}

Pendiskreditan penempatan posisi tokoh perempuan di dalam kedua iklan korporasi tersebut sungguh merupakan ketimpangan karena secara implisit melecehkan perempuan. Ketidakadilan yang terjadi dalam penentuan peran dalam iklan tersebut, tampaknya muncul akibat stereotip terhadap perempuan dalam masyarakat. Dalam iklan versi Ibu dan anak, Ibu berada di ruang domestik, yaitu di dapur, sedang melakukan pekerjaan domestik, yaitu membuat kue. Anak laki-lakinya digambarkan hanya mendampingi tanpa membantu ibunya, dan ditampilkan sebagai sesosok yang rasional dan mengingatkan Ibunya akan nilai kesabaran saat Ibunya tampak akan meluapkan emosinya. Penggambaran stereotip sifat perempuan ini juga tampak pada iklan potret. Sang Ayah (laki-laki), walaupun berada di ruang domestik (di rumah), digambarkan sebagai seorang arsitek, yang bekerja di rumah atas pilihannya sendiri. Anak perempuannya yang baru pulang sekolah, dengan emosi yang meluap-luap bercerita tentang harinya di sekolah kepada Ayahnya. Sang Ayah, sebagai seorang lakilaki digambarkan menanggapi cerita anaknya dengan tenang, dan ketika pada bagian akhir iklan, ia hanya melakukan sebuah tindakan sederhana yang rasional untuk menyadarkan anak perempuannya yang sedang emosi. Entah secara sadar atau tidak, tampilan media membentuk stereotip perempuan yang terkesan mendiskreditkan.

Seorang pemimpin biro iklan menegaskan bahwa iklan selalu mengikuti citra masyarakat, “Kalau masyarakatnya stereotip, ya, iklan akan stereotip juga". Perempuan hanya dianggap sebagai objek pemikat lawan jenis dan kaum kapitalis, yang disebut produsen atau pengiklan. Para produsen ini dengan mata yang jeli dan pikiran yang kreatif telah membuat kaum perempuan sedemikian rupa sehingga mempertebal kantong kaum kapitalis (Ibrahim, 1998: 57). Dengan demikian, dominasi kapitalis ikut menyuburkan dunia periklanan yang stereotip gender ini.

Kedua iklan ini akan sangat menarik perhatian bila kemudian dikaitkan dengan adanya dominasi kapitalis dan stereotip gender yang ada dalam iklan tersebut. Dominasi kapitalis dan dunia patriarki merupakan ideologi yang menyebabkan terjadinya penindasan terhadap kaum perempuan (Tong, 2006: 29). Sementara Michel Foucault, seorang filsuf Prancis lebih jauh meyakinkan bahwa institusi-institusi ideologis memiliki kekuatan-kekuatan diskursif tentang gender. Pada masa lalu kekuatan diskursif itu disampaikan oleh sekolah, keluarga, dan beberapa tempat ibadah. Dalam kebudayaan pasca-industri, media massa termasuk dalam lembaga berkekuatan ideologis tadi.

Perempuan dalam iklan umumnya direpresentasikan sebagai figur yang cantik, seksi, anggun, mengurus masalah domestik (rumah tangga), objek seksual, bergantung, pasif, dan sub-ordinatif di hadapan laki-laki. Sedangkan laki-laki digambarkan sebagai sosok agresif, dominan, superior, dimitoskan sebagai pelindung, kuat, jantan, perkasa, berada di wilayah publik (di luar rumah) dan menjadi decision maker. Perbedaan gender (gender differences) tersebut berlangsung terus menerus dalam sejarah yang sangat panjang dan kompleks hingga sekarang. Perbedaan itu dibentuk, disosialisasikan, diperkuat, bahkan dikonstruksikan secara sosial dan tidak dapat diubah lagi, sehingga perbedaan gender dianggap dan dipahami sebagai suatu kodrat. Berbagai pembedaan 'maskulinitas' dan 'feminitas' akhirnya memunculkan stereotip tertentu yang disebut stereotip gender. Stereotip kadang bersifat positif dan kadang negatif. 'Keindahan' yang dimiliki perempuan membentuk stereotip dan membawa perempuan ke sifat-sifat sekitar 'keindahan' seperti digambarkan sebagai objek seksual, cantik, lemah lembut, tidak asertif (pasif). Eksploitasi ini menghadirkan konsepsi pemaknaan perempuan tidak lebih sebagai sebuah benda. Tubuh dan semua atribut perempuan dieksploitasi sebagai objek tanda (sign object) dan bukannya sebagai subjek (Widyatama, 2006: 45).

Berdasarkan paparan di atas, peneliti berusaha untuk membongkar bagaimana ideologi kreator yang berada di balik penciptaan iklan tersebut dalam menciptakan makna yang terkandung pada teks iklan dan membentuk stereotip gender serta mencerminkan dominasi kapitalis. Pertanyaan penelitian ini, yaitu: seperti apa ideologi kreator kedua iklan tersebut memengaruhi pembuatan iklan. Seperti apa 
stereotip gender dibalik kedua iklan tersebut. Dan, seperti apa dominasi kapitalis dibalik kedua iklan tersebut.

Mengacu pada identifikasi permasalahan di atas, tujuan penelitian ini adalah untuk membongkar ideologi pencipta iklan di balik iklan korporasi Gudang Garam di bulan Ramadan versi "Anak dan Ibu" dan versi "Potret"; untuk membongkar stereotip gender di balik iklan korporasi Gudang Garam di bulan Ramadan versi "Anak dan Ibu" dan versi "Potret"; dan untuk membongkar dominasi kapitalis di balik iklan korporasi Gudang Garam di bulan Ramadan versi "Anak dan Ibu" dan versi "Potret".

\section{Teori Wacana Michael Foucault}

Foucault merupakan orang yang memperkenalkan wacana mutakhir. Menurut Foucault, wacana adalah sesuatu yang memproduksi yang lain (sebuah gagasan, konsep, atau efek). Wacana dapat dideteksi karena secara sistematis suatu ide, opini, konsep, dan pandangan hidup dibentuk dalam suatu konteks tertentu sehingga memengaruhi cara berpikir dan bertindak tertentu (Eriyanto, 2005: $65)$.

Untuk meneliti adanya kuasa di dalam sebuah praktik sosial, Foucault menyampaikan dua pendekatan, yaitu pendekatan arkeologis yang menitikberatkan pada dimensi meterial sejarah untuk menunjukkan bahwa subjek bukanlah entitas abstrak melainkan makhluk yang mewujud (embodied being). Pendekatan kedua disebut genealogi pengetahuan/kuasa, untuk menunjukkan bahwa pengetahuan dan kekuasaan merupakan bentuk-bentuk kontrol dan cara-cara mengorganisisasi subjektivitas yang saling tergantung dan saling menopang (Cavallaro, 2004: 161-162).

Dalam menganalisis masalah stereotip gender dan dominasi kapitalis dalam iklan, peneliti mengambil pendekatan genealogis dengan kategorisasi perempuan dan gender, seperti halnya patriarki dan penindasan. Dalam merealisasikan tujuan masih terdapat pemisahan gender yang kuat terutama dalam pengambilan keputusan. Misalnya dalam kedua iklan yang diteliti, pria masih diposisikan sebagai pihak yang lebih rasional, sementara perempuan sebagai pihak yang lebih emosional.

\section{Konsep Ideologi Louis Althusser}

Teori ideologi yang disampaikan oleh Athusser mengombinasikan teori Marxist dan psikoanalisis. Ada dua gagasan penting dalam memosisikan subjek dan objek. Pertama, gagasan Althusser mengenai interpelasi yang berhubungan dengan pembentukan subjek ideologi dalam masyarakat. Argumentasi dasarnya adalah aparatus ideologis (ideological state aparatus), adalah organ yang secara tidak langsung mereproduksi kondisi-kondisi produksi dalam masyarakat. Dalam satu masyarakat kapitalis, misalnya pekerja, harusnya dibuat mengakui atau menerima posisi mereka dalam masyarakat dan menerima peranan yang ada dalam diri mereka. Bagi Althusser, dalam cara ini individu ditempatkan sebagai subjek. Seorang individu disadarkan mengenai posisinya dalam masyarakat, ia menjadi subjek dalam dua dunia: subjek sebagai individu dan subjek dari negara atau kekuasaan. Subjek dan pengakuan akan posisi ini dihubungkan secara imajiner dengan kondisi dari hubungan seorang individu dengan keseluruhan produksi makna yang ada dalam masyarakat. Althusser menyebut proses ini sebagai interpelasi, yang melaluinya posisi seseorang ditempatkan dalam masyarakat. Interpelasi di sini mengonstruksi seseorang, membentuk subjek dalam posisinya dengan masyarakat, dan bagaimana seharusnya ia bertindak. Gagasan Althusser yang kedua adalah mengenai kesadaran. Jika interpelasi berhubungan dengan bagaimana individu ditempatkan sebagai subjek dalam tata sosial, kesadaran berhubungan dengan penerimaan individu tentang posisi-posisi itu sebagai suatu kesadaran. Ia menerima hal itu sebagai suatu kenyataan, suatu kebenaran (Eriyanto, 2005: 206-207). Dalam kedua iklan yang diteliti, akan dilihat bagaimana perempuan ditempatkan dibandingkan posisi laki-laki. 


\section{Konsep Hegemoni Antonio Gramsci}

Institusi di masyarakat yang mengarahkan terjadinya hegemoni terhadap nilai-nilai tertentu adalah media massa. Bahasa dalam media menurut Gramsci merupakan sarana penting untuk melayani fungsi hegemoni. Melalui bahasa orang diarahkan menilai dan memandang problematika sosial dalam kerangka yang sudah ditentukan oleh satu kelas sosial tertentu. Pendekatan kultural ini efektif karena dalam memengaruhi masyarakat bersifat persuasif (Sunarto, 2002: 105). Bahasa menjadi senjata terselubung yang dipergunakan oleh pihak yang memiliki kekuasaan lebih untuk menekan dan membuat diam mereka yang tersubordinasi. Dalam hubungan laki-laki dengan perempuan, perempuan menerima secara sukarela dan menyetujui kekuasaan laki-laki atasnya sebagaimana dibentuk oleh sejarah.

Pada iklan, yang dimaksud bahasa adalah gambaran dan kata-kata yang disampaikan melalui aktor-aktor yang berperan di dalamnya. Melalui iklan yang diputar secara berulang-ulang di beberapa stasiun televisi, ideologi kreator iklan yang terdapat dalam iklan itu otomatis juga akan ditransfer ke dalam benak khalayak. Ini berarti media komunikasi cenderung tidak lagi menyajikan makna dan kebenaran, tetapi justru menyampaikan sebuah dunia rekaan dari kreator iklan untuk memenuhi kepentingan-kepentingan kapitalis yang diwakilinya.

\section{Teori Feminisme Marxis}

Feminis Marxis menyatakan bahwa tidak mungkin bagi semua orang, terutama perempuan, untuk mencapai kebebasan yang sejati dalam masyarakat yang berdasarkan kelas, masyarakat yang kekayaannya dihasilkan oleh yang tidak berkekuasaan (yang jumlahnya banyak) berakhir di tangan yang berkekuasaan (yang jumlahnya sedikit) (Tong, 2006: 127). Kaum feminis Marxis menitikberatkan pada permasalahan gambaran sifat dan fungsi pekerjaan perempuan di bawah kapitalisme yang dianggap sebagai peremehan pekerjaan perempuan. Perempuan semakin dianggap sebagai konsumen semata, seolah-olah peran laki-laki adalah untuk menghasilkan upah, sementara peran perempuan adalah menghabiskannya untuk "produk yang tepat dari industri kapitalis". Menurut Margareth Benston, sesungguhnya perempuan merupakan kelas-yaitu kelas manusia "yang bertanggung jawab atas produksi nilai guna sederhana dalam kegiatan yang diasosiasikan dengan rumah dan keluarga”. Feminis Marxis percaya bahwa pekerjaan perempuan membentuk pemikiran perempuan dan karena itu membentuk juga "sifat-sifat alamiah” perempuan (Tong, 2006: 141). Dalam kedua iklan yang diteliti akan dilihat sifat-sifat perempuan yang ditonjolkan oleh media melalui aktoraktor dalam iklan tersebut.

\section{Teori Semiotika Roland Barthes}

Pendekatan semiotik Roland Barthes terhadap wacana terarah secara khusus kepada mitos. Mitos dipahami sebagai sebuah tipe tuturan. Barthes memahami wacana sebagai tuturan (parole). Sehingga, dapat disimpulkan bahwa mitos hanya merupakan sebuah tipe wacana, yang keberadaannya dikontrol dalam kerangka kultural dan merupakan hasil refleksivitas yang terbalik.

Seperti yang telah dituturkan oleh Cobley dan Jansz dalam Sobur (2006: 68) bahwa dalam setiap esainya, Barthes membahas fenomena keseharian yang luput dari keseharian, dengan konsep utamanya adalah bahwa konotasi yang terkandung dalam mitologi-mitologi biasanya merupakan hasil konstruksi yang cermat. Satu hal yang ditekankan oleh Barthes dalam kajiannya, yaitu tentang tanda dan peran pembaca (reader) yang memunculkan sebuah sistem yang disebut sistem pemaknaan tataran kedua, yang dibangun di atas sistem lain yang telah ada sebelumnya. Sistem kedua oleh Barthes disebut dengan konotatif. Dalam konsep Barthes, tanda konotatif tidak sekadar memiliki makna tambahan namun juga mengandung kedua bagian tanda denotatif yang melandasi keberadaannya. 


\begin{tabular}{|c|c|c|}
\hline 1. signifier (penanda) & 2. signified (petanda) & \\
\hline \multicolumn{2}{|c|}{ 3. denotative sign (tanda denotatif) } & \\
\hline \multicolumn{2}{|c|}{$\begin{array}{l}\text { 4. CONNOTATIVE SIGNIFIER } \\
\text { (PENANDA KONOTATIF) }\end{array}$} & $\begin{array}{l}\text { 5. CONNOTATIVE SIGNIFIED (PETANDA } \\
\text { KONOTATIF) }\end{array}$ \\
\hline \multicolumn{3}{|c|}{ 6. CONNOTATIVE SIGN (TANDA KONOTATIF) } \\
\hline
\end{tabular}

Gambar 1 Peta Tanda Roland Barthes

(Sumber: Cobley \& Jansz , 1999 dalam Sobur, 2006: 69)

Dalam kerangka Barthes, konotasi identik dengan operasi ideologi, yang disebut sebagai 'mitos', dan berfungsi untuk mengungkapkan dan memberikan pembenaran bagi nilai-nilai dominan yang berlaku dalam suatu periode tertentu. Seperti halnya Marx, Barthes juga memahami ideologi sebagai kesadaran palsu yang membuat orang hidup di dalam dunia yang imajiner dan ideal, meski realitas hidup yang sesungguhnya tidaklah demikian. Menurut Budiman dalam Sobur (2006: 71), Ideologi ada selama kebudayaan ada. Kebudayaan mewujudkan dirinya dalam teks-teks dan, dengan demikian, ideologi pun mewujudkan dirinya melalui berbagai kode yang merembes masuk dalam teks, dalam bentuk penanda-penanda penting, seperti tokoh, latar, sudut pandang, dan lain-lain.

Pendekatan Semiotik menekankan pandangannya pada bentukan dan makna yang digunakan individu dalam konteks budaya untuk memproduksi maknanya. Ini berarti bahwa budaya memegang peranan penting dalam mengubah pengggunaan bahasa. Penggunaan dan penerimaan bahasa yang terkait dengan social agreement (kesepakatan sosial) inilah yang kemudian menentukan pemaknaan atas realita yang ada, yang direpresentasikan oleh tanda-tanda yang telah disepakati bersama. Semiotik menggunakan istilah tanda untuk menjelaskan bagaiman makna atau pemaknaan diproduksi secara sosial. Beberapa ciri-ciri yang dimiliki tanda, yaitu: (1) sebuah tanda memiliki bentuk fisik, yang disebut signifier (penanda) seperti model potongan rambut atau lampu lalu lintas; (2) sebuah tanda mengacu kepada sesuatu selain dirinya, yang disebut signified (petanda/yang ditandai), hal ini menekankan pada sebuah konsep yang dimaksud, bukan mengacu pada hal nyata yang ada di dunia; (3) semiotik menekankan bahwa persepsi akan realita adalah dibentuk dan dikonstruksi sendiri oleh kata dan tanda yang digunakan dalam beragam konteks sosial (Branston \& Stafford, 2003: 11).

Pada kedua iklan yang diteliti, akan dilihat penanda dan petanda yang merepresentasikan ideologi kreator iklan, menciptakan steretip gender, dan mencerminkan dominasi kapitalis yang ada di dalamnya.

\section{METODE PENELITIAN}

Penelitian ini menggunakan paradigma kritis dengan menggunakan analisis wacana kritis. Dalam analisis wacana kritis (Critical Discourse Analysis/CDA), wacana di sini tidak dipahami semata sebagai studi bahasa. Bahasa dianalisis bukan dengan menggambarkan dari aspek kebahasaan semata, tetapi juga menghubungkan konteks, yang berarti bahwa bahasa itu dianggap digunakan untuk tujuan atau praktik tertentu, termasuk di dalamnya praktik kekuasaan (Eriyanto, 2005: 7). Analisis wacana kritis melihat wacana sebagai pemakaian bahasa dalam tuturan dan tulisan sebagai praktik sosial yang menyebabkan sebuah hubungan dialektis di antara peristiwa diskursif tertentu dengan situasi, institusi, dan struktur sosial yang membentuknya. Analisis wacana kritis melihat bahasa sebagai faktor penting, yaitu bagaimana bahasa digunakan untuk melihat ketimpangan kekuasaan dalam masyarakat. Analisis Wacana Kritis menyelidiki bagaimana melalui bahasa kelompok sosial yang ada saling bertarung dan mengajukan versinya masing-masing. 
Ada beberapa pendekatan utama dalam analisis wacana kritis. Namun dalam menganalisis kedua iklan korporasi Gudang Garam ini, akan digunakan pendekatan Analisis Wacana Prancis (French Discourse Analysis). Pendekatan ini dikenal dengan nama pendekatan Pecheux. Dalam pandangan Pecheux, bahasa dan ideologi bertemu pada pemakaian bahasa, dan materialisasi bahasa pada ideologi. Keduanya, kata yang digunakan dan makna kata tersebut, menunjukkan posisi seseorang dalam kelas tertentu. Bahasa adalah medan pertarungan, tempat berbagai kelompok dan kelas sosial berusaha menanamkan keyakinan dan pemahamannya. Pecheux memusatkan perhatian pada efek ideologi dari formasi diskursus yang memosisikan seseorang sebagai subjek dalam situasi sosial tertentu. Mengutip Althusser, ia menekankan bagaimana seseorang ditempatkan secara imajiner dalam posisi tertentu, wacana menyediakan efek ideologis berupa pemosisian ideologi seseorang.

Metode penelitian ini menggunakan analisis wacana semiotik. Penelitian semiotik merupakan salah satu bentuk analisis teks media yang bersifat kualitatif. Secara etimologis, istilah semiotik berasal dari kata Yunani semeion yang berarti tanda. Dalam penelitian ini semiotika yang dimaksudkan adalah ilmu yang mempelajari sederetan luas objek-objek peristiwa, seluruh kebudayaan sebagai tanda. Van Zoest mengartikan semiotik sebagai ilmu tanda dan segala yang berhubungan dengannya: cara berfungsinya, hubungannya dengan kata lain, pengirimannya dan penerimaannya oleh mereka yang mempergunakannya (Sobur, 2001:96).

Objek kajian penelitian ini adalah kedua iklan korporasi Gudang Garam yang diputar selama bulan Ramadan 2007, yaitu versi Ibu dan Anak serta versi Potret. Kedua iklan korporasi ini dianalisis menggunakan pisau analisis semiotika teks Roland Barthes (1915-1980) yang merupakan pengembangan dari strukturalisme semiotik teks (Winfreid, 1990:310-313). Barthes melontarkan konsep tentang konotasi dan denotasi sebagai kunci dari analisisnya. Barthes menggunakan versi yang jauh lebih sederhana saat membahas model 'glossematic sign' (tanda-tanda glossematic). Mengabaikan dimensi dari bentuk dan substansi, Barthes mendefinisikan sebuah tanda (Sign) sebagai sebuah sistem yang terdiri dari (E) sebuah ekspresi atau signifier dalam hubungannya (R) dengan content (atau signified) (C): ERC.

Media massa menciptakan mitologi-mitologi atau ideologi sebagai sistem konotatif sekunder dengan mencoba memberikan fondasi alamiah dari pesan-pesan mereka agar dianggap sebagai sebuah sistem denotatif primer. Barthes meredefinisi konsep denotation sebagai hasil akhir dari sebuah proses konotasi, efek dari sebuah penutupan semiotik. Denotasi bukanlah pengertian pertama, tetapi seolaholah begitu. Di bawah ilusi tersebut, akhirnya tidak lebih dari konotasi yang terakhir, mitos yang unggul dimana teks seolah-olah menjadi bahasa yang alamiah (Winfried, 1990:312).

Dalam pengolahan data iklan Korporasi Gudang Garam versi Ibu dan Anak serta versi Potret adalah memahami pesan yang disampaikan dalam bentuk audio, visual, dan gerak. Bentuk pesan tersebut pada dasarnya merupakan sejumlah tanda. Dalam kajian semiologi, iklan adalah seperangkat tanda yang berfungsi menyampaikan sejumlah pesan, sedangkan semiologi sendiri merupakan ilmu tentang tanda. Menurut Roland Barthes (dipengaruhi oleh pemikiran Saussure), dalam tanda terdapat kesatuan signifier (penanda) aspek citra-bunyi (semacam kata atau representasi visual) dan signified (petanda) gambaran mental atau konsep citra bunyi disandarkan (Sobur, 2002). Kedua unsur ini seperti dua sisi mata uang, tidak dapat dipisahkan antara penanda dan petanda dalam membentuk tanda. Hubungan antara penanda dan petanda dinamakan signification. Dengan kata lain, signification adalah upaya dalam memberi makna terhadap dunia.

Model analisis yang akan digunakan adalah model analisis dari Sara Mills. Ia menitikberatkan perhatiannya pada wacana mengenai feminisme: bagaimana perempuan ditampilkan dalam teks, baik dalam novel, gambar, foto ataupun dalam berita. Yang dilakukan oleh Sara Mills sering disebut sebagai perspektif feminis. Perspektif wacana feminis menunjukkan bagaimana teks bias dalam menampilkan perempuan. Perempuan cenderung ditampilkan dalam teks sebagai pihak yang salah, marjinal apabila dibandingkan dengan pihak laki-laki. Ketidakadilan dan penggambaran yang buruk 
mengenai perempuan inilah yang menjadi sasaran utama dari tulisan Mills. Selain itu, Sara Mills juga memusatkan perhatian pada bagaimana pembaca dan penulis ditampilkan dalam teks. Bagaimana pembaca mengidentifikasi dan menempatkan dirinya dalam penceritaan teks. Posisi semacam ini akan menempatkan pembaca pada salah satu posisi dan memengaruhi bagaimana teks itu hendak dipahami dan bagaimana pula aktor sosial ini ditempatkan. Cara penceritaan dan posisi-posisi yang ditempatkan dan ditampilkan dalam teks ini membuat satu pihak menjadi legitimate dan pihak lain menjadi illegitimate.

Posisi sebagai subjek atau objek dalam representasi ini mengandung muatan ideologis tertentu. Dalam hal ini bagaimana posisi ini turut memarjinalkan posisi perempuan ketika ditampilkan dalam teks. Pertama, posisi ini menunjukkan dalam batas tertentu sudut pandang penceritaan yang dijelaskan dalam sudut pandang laki-laki. Teks yang disajikan pada khalayak adalah suara tunggal laki-laki sebagai pencerita. Dengan demikian, khalayak bergantung sepenuhnya pada narator yang di sini bukan hanya menampilkan dirinya sendiri, tetapi juga sebagai juru warta kebenaran. Kedua, sebagai subjek representasi, pihak laki-laki di sini memiliki otoritas penuh dalam mengabsahkan penyampaian peristiwa tersebut kepada khalayak. Karena posisinya sebagai subjek, ia bahkan bukan hanya mempunyai keleluasaan menceritakan peristiwa, tetapi juga menafsirkan berbagai tindakan yang membangun peristiwa tersebut, dan kemudian hasil penafsirannya digunakan untuk membangun pemaknaan yang disampaikan kepada khalayak. Ketiga, karena proses pendefinisian itu bersifat subjektif, tentu saja sukar dihindari kemungkinan pendefinisian peristiwa secara sepihak atau kelompok lain. Ia bukan hanya mendefinisikan dirinya sendiri, tetapi juga mendefinisikan pihak lain dalam perspektif atau sudut pandangnya sendiri (Eriyanto, 2005: 202-203).

\section{HASIL DAN PEMBAHASAN}

\section{Analisis dan Interpretasi}

Analisis data terhadap iklan Korporasi Gudang Garam versi Ibu dan Anak serta versi Potret menggunakan analisis wacana semiotik Roland Barthes, yang selain melihat hubungan antara penanda dan petanda (signifikansi) juga akan membaca sejumlah tanda (sign) terutama dalam bentuk simbol dan indeks yang terdapat dalam beberapa scene iklan tersebut. Hal lainnya adalah menemukan 'mitos' untuk melihat benang merah isi teks iklan tersebut. Dengan demikian, pembahasan akan melihat pada bagaimana dan dalam hal apa stereotip gender dan representasi dominasi kapitalis diperlihatkan dalam iklan tersebut. Peneliti juga menggunakan metode analisis Sara Mills untuk melihat bagaimana posisi-posisi aktor ditampilkan dalam teks. Posisi-posisi ini dalam arti siapa yang menjadi subjek penceritaan dan siapa yang menjadi objek penceritaan akan menentukan bagaimana struktur teks dan bagaimana makna diperlakukan dalam teks secara keseluruhan. Ada 3 (tiga) scene yang terdiri dari 9 gambar dari kedua versi iklan yang dianalis untuk melihat bagaimana dan dalam hal apa stereotip gender dan representasi dominasi kapitalis.

\section{Analisis Semiotika terhadap Iklan}

Sara Mills menitikberatkan perhatiannya pada wacana mengenai feminisme: bagaimana perempuan ditampilkan dalam teks, dalam penelitian ini adalah iklan. Sara Mills menunjukkan bagaimana teks bias dalam menampilkan perempuan. Sara Mills juga melihat pada bagaimana posisiposisi aktor ditampilkan dalam teks. Posisi-posisi ini dalam arti siapa yang menjadi subjek penceritaan dan siapa yang menjadi objek penceritaan akan menentukan bagaimana struktur teks dan bagaimana makna diperlakukan dalam teks secara keseluruhan. 
Althusser juga melihat bagaimana posisi individu ditempatkan sebagai subjek. Subjek dan pengakuan posisi dihubungkan secara imajiner dengan kondisi dari hubungan dengan keseluruhan produksi makna yang ada dalam masyarakat. Althusser menjelaskan tentang bagaimana seseorang akan ditempatkan posisinya dalam masyarakat, dikonstruksi dan dibentuk sebagai subjek, dan bagaimana ia seharusnya bertindak. Gagasan Althusser yang kedua adalah mengenai kesadaran, bahwa interpelasi berhubungan dengan bagaimana individu ditempatkan sebagai subjek dalam tata sosial, dan kesadaran berhubungan dengan penerimaan individu tentang posisi-posisi itu sebagai suatu kesadaran. Mereka menerima hal itu sebagai suatu kenyataan, suatu kebenaran. Berdasarkan pemahaman tersebut, peneliti mencoba menganalisis kedua iklan ini dengan semiotika Roland Barthes untuk melihat bagaimana perempuan ditempatkan dalam iklan tersebut.

\section{Scene 1 versi Ibu dan Anak}

Tanda yang berupa setting lokasi yang ditampilkan dalam scene ini (gambar 2) merepresentasikan posisi dan status ekonomi aktor, yaitu kalangan menengah ke atas. Hal itu dapat dilihat dari setting lokasi yang memperlihatkan Ibu dan Anak berada di sebuah rumah yang memiliki pemisahan antara dapur kotor dan dapur bersih. Dapur kotor biasanya digunakan untuk memasak makanan sehari-hari dan letaknya di belakang rumah. Biasanya yang memasak di sana adalah pembantu rumah tangga. Sedangkan dapur bersih adalah tempat para Ibu jika mereka ingin memasak sendiri, dan jenis masakan yang dimasak di sana biasanya adalah kue-kue, puding ataupun jenis-jenis makanan lainnya yang tidak berbau tajam dengan teknik pembuatan sederhana. Lazimnya, dapur bersih ini terletak bersambungan dengan rumah utama, bahkan seringkali bersambungan dengan ruang makan (konsepnya open kichen).

Tanda-tanda berupa property dan wardrobe yang digunakan dalam iklan ini, mencerminkan kapitalis. Perabot yang terdapat dalam dapur berupa microwave, food processor, kompor tanam, wadah-wadah aneka bumbu, set pisau dapur, aneka saus, kitchen set, dan sebagainya terlihat menggunakan peralatan yang modern dan mewah. Pakaian yang digunakan ibu bermerek 'et cetera', sedangkan anak menggunakan kaos Osh Kosh B'Gosh yang harganya minimal sebesar dua ratus ribu rupiah. Pakaian yang semahal ini digunakan di rumah, padahal orang kebanyakan menggunakan baju seharga itu untuk bepergian bahkan ada yang menggunakannya ke pesta.

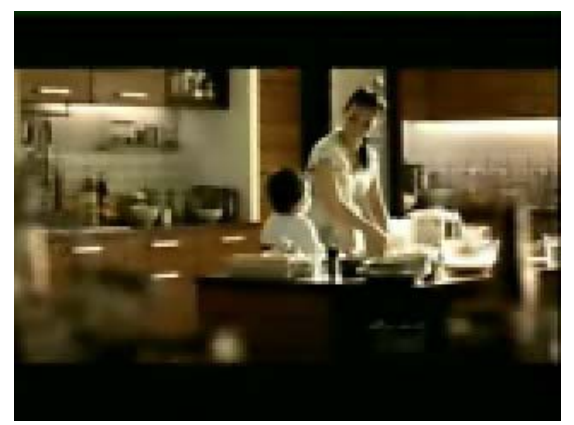

Gambar 2 iklan Gudang Garam scene 1 versi ibu dan anak

\section{Scene 1 versi Potret}

Sama seperti versi iklan Ibu dan Anak di atas, versi Potret (gambar 3) juga mencerminkan modernitas dan kelas sosial aktor tersebut berasal, yaitu menengah ke atas. Setting rumah dan ruangan tempat aktor berinteraksi memperlihatkan modernitas dan kemapanan. Perabotan untuk dekorasi ruangan sangat mengikuti tren, yaitu modern minimalis. Hal ini terlihat pada bentuk kursi, sofa, meja, rak buku, lukisan di dinding, pilihan tanaman, dan warna cat dinding. Pakaian yang digunakan si Ayah bermerek St.Michael. Kaca mata dan jam tangan yang dikenakannya bermerek Tag Hueuer. Mobile 
phone si Ayah bermerek Samsung yang pada saat iklan ini ditayangkan di televisi adalah tipe terbaru. Pakaian si Anak adalah seragam sekolah dasar pada umumnya, namun terihat begitu bersih, dan begitu cemerlang.

Pada scene ini si Ayah digambarkan sedang menyelesaikan maket (miniatur bangunan), yang memperlihatkan pekerjaannya sebagai seorang arsitek. Profesi sebagai arsitek, merupakan sebuah pekerjaan yang sekarang dinilai sebagai sebuah pekerjaan yang seksi dan happening. Ini adalah sebuah jenis pekerjaan yang tidak mengharuskan seseorang untuk bekerja di rumah dengan jam kerja mengikat nine to five. Pekerjaan ini dapat dikerjakan di kantor maupun di rumah, dan tidak mengharuskan pakaian formal (kemeja, celana kain dan dasi).

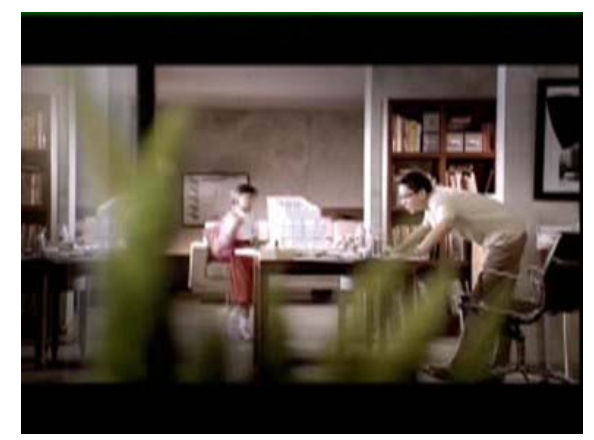

Gambar 3 iklan Gudang Garam scene 1 versi potret

\section{Scene 2}
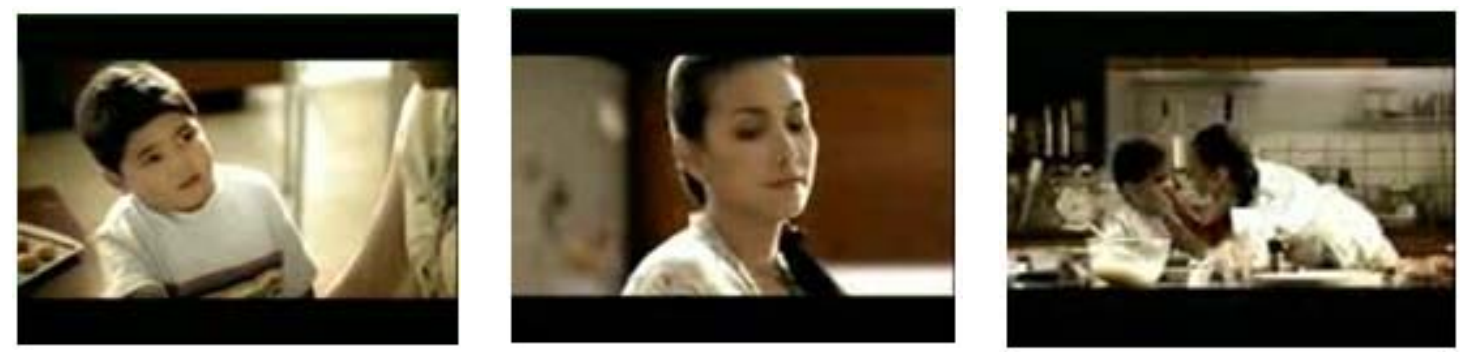

Gambar 4 iklan Gudang Garam scene 2

Ma, buka puasa kapan sih, Ma?

Maghrib, yah?

Mama buat apa sih? Masak kue, yah?

Enak nggak, Ma?

Aku lapar, Ma!

Kalo ngicipin batal nggak, Ma?

Dikiiiiiitttttt aja....

Hhhhhhhaaaaaaaaaaakkkkkkkhhhhhh (menumpahkan tepung)

Ma, khan kalo orang puasa musti sabar, yah, Ma....

Scene kedua (gambar 4) diambil dari iklan versi Ibu dan Anak, dengan ketiga gambar yang mengambil ekspresi-ekspresi utama dalam iklan. Iklan ini memperlihatkan adegan seorang anak yang datang mengganggu Ibunya yang sedang membuat kue di dapur. Anak ini memberondong Ibunya dengan pertanyaan-pertanyaan yang menggangu konsentrasi dalam membuat kue, dan hal itu 
mengakibatkan emosi si Ibu memuncak, apalagi si Anak secara teledor mengayunkan roller (penggilas/penipis kue), sehingga tepung yang ada di atas meja tumpah.

Emosi si Ibu hampir saja tidak terkontrol karena perbuatan si anak. Namun saat si anak mengingatkan Ibunya bahwa pada bulan puasa seyogyanya setiap orang bisa mengandalikan emosi, si Ibu tersadar bahwa pernyataan anaknya benar. Si Ibu kemudian meredam kekesalan dan mengubahnya ke dalam bentuk gemas (mencubit pipi si anak sembari tersenyum).

Di sini posisi subjek adalah anak, dan Ibu adalah objek. Karena dalam iklan ini, anak menunjukkan bahwa dia memiliki kekuasaan tertentu untuk mengopresi ibunya melalui kata-kata yang kekanakan, tetapi memiliki kuasa untuk mengubah sikap serta emosi si Ibu.

\section{Scene 3}
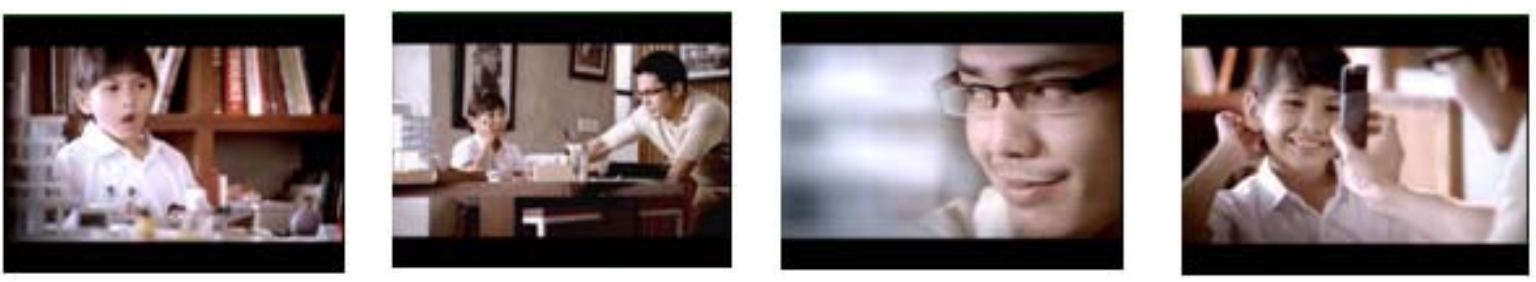

Gambar 5 iklan Gudang Garam scene 3

Anak : Pah..pah.. sebel deh pah..

Pah, masa temenku si Vina, di sekolah bulan puasa gini gosipin orang..

Gosipin aldi, rino, sampe aku juga digosipin! Bawel..banget!

Puasa kan harusnya ibadah ya Pah, kok ada sih orang yang kaya gitu?

Ayah : Ada.. Nih...

Anak: Ehe..he..he..he.. (tertawa)

Gambar-gambar dalam scene 3 ini (gambar 5) diambil dari iklan versi potret. Di sini digambarkan seorang anak yang saat pulang sekolah mencari Ayahnya dan langsung curhat, meluapkan segala emosi dan kekesalan dalam hatinya, karena dia mengalami hari yang buruk di sekolahnya. Dia mengeluhkan seorang teman sekolahnya yang di saat bulan puasa menggosipkan teman-teman di sekolahnya, termasuk dirinya sendiri. Saat sang anak sibuk mencurahkan isi hatinya, sang bapak tidak menghentikan kegiatannya bekerja sama sekali. Ketika si anak melontarkan pertanyaan mengapa ada orang yang tetap menggosip di bulan puasa, sang ayah baru melirik ke anaknya sambil tersenyum. Ia kemudian mengambil handphone, memotret anaknya, kemudian menunjukkan hasil gambarnya kepada anaknya, dengan maksud menyadarkan anaknya, bahwa tanpa sadar anaknya juga telah melakukan kesalahan yang sama seperti temannya yang menggosip di sekolah itu. Sang anak kemudian tersenyum malu dan tersipu.

Dalam iklan ini, meski anak terlihat lebih aktif secara verbal, sementara ayah terlihat lebih pasif. Namun posisi subjek justru ditempati oleh ayah, dan anak berada pada posisi objek. Ayah tidak menasihati anak secara verbal, tetapi memperlihatkan kedigdayaannya sebagai laki-laki dengan katakata yang sangat minim namun punya kuasa utk menyadarkan anak perempuannya.

\section{Analisis Konteks Penulis}

Dalam penelitian ini, penulis hanya berfokus pada konteks penulis, untuk melihat bagaimana ideologi penulis masuk ke dalam penciptaan iklan, seperti disebutkan oleh Gramsci, bahwa bahasa dalam media, termasuk iklan, merupakan sarana penting untuk melayani fungsi hegemoni. Melalui 
bahasa orang diarahkan menilai dan memandang problematika sosial dalam kerangka yang sudah ditentukan oleh satu kelas sosial tertentu, dalam hal ini adalah kreator iklan.

Narasumber yang kami wawancara adalah creative director Otocomm, laki-laki berusia 36 tahun, bersuku Batak dan bergama Islam. Ia sudah menikah, mempunyai dua orang anak laki-laki, berusia 6 dan 4 tahun, yang bersekolah di sekolah Islam Internasional. Istrinya dulu seorang Media Planner di sebuah biro iklan, tetapi kini hanya ibu rumah tangga dengan alasan harus mengurus anak. Hobi informan adalah mengumpulkan pernak-pernik tokoh kartun Tintin, sedang hobi istrinya mengumpulkan miniatur furnitur karya desainer dalam dan luar negeri. Informan merupakan lulusan Fakultas Senirupa dan Desain ITB. Pengalaman kerjanya cukup mengesankan, selama 12 tahun selalu dalam bidang creative di biro iklan baik yang bertaraf nasional maupun internasional. Ayahnya adalah sarjana Antropologi UI yang kemudian bekerja sebagai guru Bahasa Inggris di SMA dan Sesko ABRI. Sebelum wafat 2 tahun yang lalu, ayahnya menjadi direktur personalia sebuah perusahaan swasta. Ibunya adalah adalah ibu rumah tangga. Setelah ayahnya wafat, Ibunya kemudian membuka TK dan mengajar di sana. Narasumber adalah anak sulung dari dua bersaudara, adiknya perempuan.

Dari latar belakang informan, terlihat bahwa informan tumbuh dan hidup dalam lingkungan yang patriarki. Oleh sebab itu, ide pembuatan iklan dan penentuan peran dalam iklan pun banyak yang dipengaruhi oleh ideologi patriarkinya yang sangat stereotip terhadap perempuan. Informan mengatakan bahwa ide iklan dibuat berdasarkan kenyataan yang ada dalam masyarakat. Namun semua kembali pada tujuan awal yaitu untuk pembentukan image yang baik sebagai pemberi pesan yang bernilai pada masyarakat. Hal ini menunjukan upaya dominasi kapitalis untuk mendapatkan hegemoni ekonomi melalui iklan. Meski secara nyata rokok adalah sumber polusi dan penyakit, perusahaan tetap ingin mendapatkan citra sebagai perusahaan yang bertanggung jawab pada masyarakat.

Pemilihan peran anak-anak yang seolah mensubordinasi orang tuanya adalah agar orang lebih memerhatikan dan merasa "tersentil" dengan isi pesan tersebut. Namun pemilihan peran orang tuanya dan setting lokasi memperlihatkan dominasi kapitalis karena menganggap bahwa sesuatu yang mewah adalah bagus. Ketika membicarakan mengenai pemilihan profesi bagi aktor ayah, penulis menghubungkannya dengan modernitas dan arsitek merupakan sebuah profesi yang dianggap sempurna untuk mewakili modernitas tersebut.

\section{SIMPULAN}

Berdasarkan hasil analisis, peneliti menyimpulkan bahwa memang benar ideologi kreator iklan yang sangat patriarki membuat teks iklan korporasi Gudang Garam yang ditayangkan di semua stasiun televisi selama bulan Ramadan 2007 itu sarat dengan adanya stereotip gender. Penempatan ayah yang seolah bekerja di sektor domestik sebenarnya hanyalah manifestasi dari ideologi patriarki yang mendominasi kaum perempuan. Hal ini disebabkan karena meski bekerja di rumah profesinya pun adalah profesi yang bagi kaum kapitalis adalah profesi yang bergengsi. Profesi arsitek yang digambarkan oleh penulis adalah profesi kaum bourjuis yang didefinisikan oleh Marx karena mereka menguasai means of production.

Tokoh ibu dalam iklan versi Ibu dan Anak terlihat sangat sarat dengan stereotip gender yang ditampilkan sebagai perempuan yang memang punya kewajiban mengurus sektor domestik meski ia bisa berkarir di sektor publik. Tokoh ibu digambarkan sebagai seorang perempuan yang tampaknya adalah perempuan bekerja, tetapi masih harus membuat kue yang merupakan pekerjaan domestik. Seperti dikatakan kaum feminis marxis bahwa perempuan akan lebih teropresi jika mereka dibiarkan bekerja di sektor publik tapi masih berkewajiban mengerjakan pekerjaan-pekerjaan domestik seperti memasak dan mengasuh anak. 
Si anak laki-laki walaupun sangat kekanak-kanakan, tetapi kemudian ia digambarkan cukup bijaksana untuk mengeluarkan sebuah kalimat yang dapat meredam kemarahan ibunya. Hal ini menampakkan ideologi patriarki yang telah tertanam walaupun tokoh laki-laki di sini ada pada diri seorang anak kecil.

Sedangkan si anak perempuan dalam iklan versi potret digambarkan cerewet dan penggerutu, yang tampaknya adalah penggambaran perempuan. Tokoh anak ini teropresi oleh tokoh ayahnya ketika setelah berkeluh kesah panjang lebar, sang ayah cukup melakukan sebuah tindakan sederhana dan mengucapkan satu kalimat pendek untuk menyadarkan dirinya dari kekhilafannya. Ia kemudian tampak malu dan tidak dapat berkata-kata lagi.

Dominasi kapitalis diperlihatkan pada pengaturan setting iklan dan barang-barang yang digunakan oleh aktor, semuanya mencerminkan kemapanan. Barang-barang yang digunakan oleh para aktor pun merek yang harganya berkisar ratusan ribu, sebuah angka yang cukup fantastis bagi sebagian besar penduduk bangsa Indonesia yang masih berada dalam kondisi ekonomi pas-pasan. Pilihan pekerjaan tokoh ayah sebagai arsitek juga merupakan gambaran dominasi kapitalis, karena pekerjaan arsitek adalah pekerjaan yang dinilai sebagai pekerjaan yang happening.

\section{DAFTAR PUSTAKA}

Baran, S. J., and Davis, D. K. (2000). Mass Communication Theory: Foundation, Ferment, and Future. Second Edition. Belmont: Wadsworth.

Bovee, C. L., and Arens, W. F. (1986). Contemporary Advertising, $2^{\text {nd }}$ ed. Illinois: Irwin.

Cavallaro, D. (2004). Critical and Cultural Theory: Teori Kritis dan teori Budaya. Yogyakarta : Niagara.

Eriyanto. (2005). Analisis Wacana, Pengantar Analisis Teks Media. Yogyakarta: LKIS.

Fiske, J. (1990). Introduction to Communication Studies. London (second edition)

McQuail, D. (2005). Mass Communication Theory. Fifth Edition. SAGE Publications.

Poerwandari, K. (2001). Pendekatan Kualitatif untuk Penelitian Perilaku Manusia, LPSP3 Fak. Psikologi UI.

Sobur, A. (2001). Analisis Teks media : Suatu Pengantar Untuk Analisis Wacana, Analisis Semiotik dan Analisis Framing. Bandung: Remaja Rosdakarya. (2006). Semiotika Komunikasi. Bandung: Remaja Rosdakarya.

Sunarto. (2002). Analisis Wacana Ideologi Gender Media Anak-anak. Penerbit Ikapi dan Ford Foundation.

Tong, R. P. (2006). Feminist Thought, Pengantar paling Komprehensif kepada Arus Utama Pemikiran Feminis. Yogyakarta: Jalasutra.

Widyatama, R. (2006). Bias Gender Dalam Iklan Televisi. Yogyakarta: Media Presindo. 